\title{
NOTES
}

\section{FOREIGN LOBBIES AND U.S. TRADE POLICY*}

\author{
Kishore Gawande, Pravin Krishna, and Michael J. Robbins*
}

Abstract-In popular discussion, much has been made of the susceptibility of government policies to lobbying by foreigners- the general presumption being that this is harmful to the home economy. However, in a trade policy context this may not be the case. If the policy outcome absent any foreign lobbying is characterized by welfare-reducing trade barriers, foreign lobbying may reduce such barriers and possibly raise welfare Using a new data set on foreign political activity in the United States, this paper investigates this question empirically. Tariffs and nontariff barriers are both found to be negatively related with foreign lobbying activity.

\section{Introduction}

A GROWING body of work in economics views trade policy as being determined not by a benign welfare-maximizing government (as was assumed in the traditional treatments of this topic) but rather by interactions between politicians and organized special interest groups. The emphasis in much of this literature (particularly on the empirical side) has been on the link between domestic industry lobbies and the government. Recent events, ${ }^{1}$ however, have shifted the focus in popular discussion (as well as in the consequent policy proposals related to campaign finance reform) to foreign lobbies and the extent to which these are involved in the political process; the general presumption being that such interactions between foreigners and the domestic government have a deleterious effect on the home economy.

In a trade policy context, however, it can be argued that bending policy in a direction that would suit foreigners may not in fact be harmful: If the policy outcome absent any involvement by foreigners is characterized by welfare-reducing (or suboptimal) trade barriers, lobbying by foreigners for reductions in such barriers may in fact shift trade policy in a direction that improves domestic consumer surplus (and possibly welfare). But is it so? Do foreign lobbies have a significant effect on U.S. trade policy? If so, by what magnitude? It is this relationship between foreign lobbies and trade barriers that this paper attempts to investigate empirically.

The theoretical foundation that we develop to motivate our estimating equations borrows extensively from the well-known model of

Received for publication April 26, 2004. Revision accepted for publication January 10, 2006.

*Texas A\&M University; Johns Hopkins University and NBER; and Bingham McCutchen LLP, respectively.

We are grateful to seminar participants at the University of Chicago University of Michigan, Pennsylvania State University, Southern Methodist University, Stanford University, Syracuse University, Texas A\&M University, University of Texas at Austin, World Bank Research Department, Yale University, and the 2002 Meetings of the American Economic Association for many helpful comments and discussions. Gawande and Krishna gratefully acknowledge the hospitality and the intellectual and financial support of the Stigler Center for Study of the Economy and the State at the University of Chicago Graduate School of Business and the International Economics Section at Princeton University, where some of this research was conducted. Financial support in the form of a Salomon faculty research grant from Brown University and a grant from the National Science Foundation (SES-0004302) is also gratefully acknowledged. Opinions are those of the authors and not of the institutions with which they are affiliated.

1 These include the widespread accusations relating to foreign campaign contributions in the 1996 U.S. presidential campaign and the conviction of Representative Jay Kim (Republican, CA) for his acceptance of illegal contributions from Korean sources. endogenous policy determination developed by Grossman and Helpman (1994)-which is altered here suitably to take account of the role of foreign lobbies. This framework assumes a government that trades off its desire to deliver a higher level of welfare to its polity with its desire for political contributions from organized industry lobbies (which, in turn, provide political contributions to the government so it may move policy in a direction that would suit them). A substantial merit of this framework, from at least the standpoint of empirical testing, is that despite its rigor and complexity, trade policy is predicted to be a simple function of relatively few variables. This, as we show, proves to be true even after foreign political involvement is introduced. In the import-competing sectors, for instance, equilibrium tariffs are simply a log-linear function of the import-penetration ratio, the import demand elasticity, the presence (or absence) of domestic and foreign lobbying activity in that sector, and, finally, a parameter that measures the emphasis that the government places on contributions relative to overall welfare. This parsimonious specification enables fairly easy econometric implementation-a task that we accomplish using econometric methodology similar to that detailed in the recent and pioneering work of Goldberg and Maggi (1999) and Gawande and Bandhyopadhyay (2000).

Our estimation results suggest that foreign lobbying has a statistically and economically significant influence on trade policy: The presence of an organized foreign lobby representing a particular industrial sector appears to have as much effect in lowering trade barriers against imports in that sector as does the presence of a domestic lobby in raising trade barriers there. Ceteris paribus, U.S. consumers gain unambiguously from the presence of foreign political activity. To evaluate the robustness of our results, we also estimate extended specifications in which we include a large number of additional explanatory variables that have been suggested in the literature as determinants of trade policy (but that emerge from outside the theoretical structure described above) ${ }^{2}$ Estimates of the parsimonious specification implied by the theory compare very well with those obtained from the extended regressions discussed above.

Overall, this paper makes the following contributions: First, it is the only formal study of foreign lobbying activity and its economic effects of which we are aware. Although several scholars and observers have commented on the presence and importance of foreign lobbying in the context of trade policy formulation, ${ }^{3}$ none has studied it in the manner or the detail that we do here. Second, a substantial component of the research effort on this paper has involved the compilation of a new data set on foreign political activity. Finally, we

\footnotetext{
${ }^{2}$ Trefler (1993), which studied the protective effect of trade barriers in a context where protection itself was treated as endogenous and reported dramatic evidence to this effect, is an excellent example of work in this tradition. As we have discussed in Gawande and Krishna (2003), a recent survey of empirical analyses in the literature on the political economy of trade policy, the use of extended specifications has the merit of (a type of) comprehensiveness-every observable variable that we conjecture to be relevant to the determination of trade policy may be included as an explanatory factor. As Rodrik (1995) has noted, however, the variables included in the right-hand side sometimes have only very tenuous links with the theories that motivate their inclusion in the regression equations.

${ }^{3}$ See, for instance, Baldwin (1985) and Hillman and Ursprung (1988).
} 
believe that our results, which run counter to much of the popular opinion on foreign lobbies, contribute to the public debate on the influence of foreign lobbies that has recently arisen in the context of discussions on campaign finance reform.

The rest of this paper proceeds as follows. Section II describes briefly the extent of foreign lobbying and the evolution of the legal context in which foreign lobbies operate in the United States. Section III describes the theoretical framework that underlies our empirical exercise. Section IV presents the econometric model and discusses data and estimation issues in detail. Section V describes our results. Section VI discusses some problematic issues that arise in our analysis and concludes with some thoughts on future research directions.

\section{Foreign Political Activity in the United States}

Government concern regarding foreign influence on policy has a long history in the United States. ${ }^{4}$ Nevertheless, as Corrado et al. (1997) note, ${ }^{5}$ for many years there was no ban or limit placed on foreign political contributions. This changed in 1938 when, in the face of evidence of Nazi money spent to influence U.S. political debate, Congress passed the so-called Foreign Agents Registration Act (FARA). This law required agents of foreign entities engaged in publishing "political propaganda" to register and disclose their activities, but it did not regulate political contributions. In 1966, after congressional hearings in 1962-1963 revealed campaign contributions to federal candidates by Philippine sugar producers and agents of the Nicaraguan president Luis Somoza, Congress moved to prohibit political contributions in any U.S. election by any foreign government, political party, corporation, or individual (except foreign nationals who were permanent residents of the United States).

The contrast with restrictions on domestic influence in the electoral process may be clarified as follows: U.S. nationals may make direct political contributions. U.S. corporations and labor unions, though generally restricted from making contributions from their treasury funds to election candidates, may still make contributions through "voluntary" funds collected by political action committees (PACs), which are composed of their employees and members respectively. ${ }^{6}$ Despite the 1966 regulations (described in the previous paragraph) seeking to prevent the influence of foreign interests on U.S. policymaking, contributions from sources with foreign ties are still allowed.

\footnotetext{
${ }^{4}$ Indeed, the potential for harmful foreign intrigue was very real to the founders and was addressed in no fewer than fifteen of the Federalist Papers. For instance, Alexander Hamilton stated his view of the corrupting influence of foreign political presence by writing in Federalist No. 22 that "One of the weak sides of republics, among their numerous advantages, is that they afford too easy an inlet to foreign corruption .... Hence it is that history furnishes us with so many mortifying examples of the prevalence of foreign corruption in republican governments. How much this contributed to the ruin of the ancient commonwealths has been already disclosed."

${ }^{5}$ The discussion that follows borrows extensively from the comprehensive Brookings survey by those authors.

${ }^{6}$ It is worth pointing out that contributions by U.S. entities may be classified as either being in hard money (which is money that is limited and otherwise regulated through federal election laws and can be used directly in connection with election for federal office) or in soft money (which is generally subject to no limits but may only be used indirectly in the political process-for such purposes as getting out the vote and issue advocacy. Corporations and unions, though banned from making hard money contributions except through PACs (as described above), may still make unlimited soft money contributions-as may individuals. However, in as much as our study is set in the 1970s, soft money contributors and contributions (which did not really assume significance until the early 1990s) are not an important consideration, and we ignore them entirely.
}

Foreign agents, that is, U.S. citizens acting as lobbyists for foreign governments or officials, foreign individuals, or foreign businesses or associations can make campaign contributions like any other U.S. citizen provided that they are registered with the Justice Department (in accordance with the FARA of 1938, which we have mentioned above) and that the contributions are made with their own funds. By all popular accounts, the fungibility of cash flows and generally lax monitoring of the activities of foreign agents has meant that in practice, agents of foreign interests have contributed actively to political campaigns on behalf of their principals. ${ }^{7}$ It is on these foreign agents that we focus our attention in this study.

A measure of the extent of foreign agent activity in absolute terms and in relation to lobbying by domestic corporate PACs can be obtained by examining the following figures. At the beginning of the time period of our study, the 1978 election cycle, there were roughly 800 corporate PACs in operation. In comparison, in the same period, there were approximately 250 foreign agents in active operation. In the 1978 election cycle, these corporate PACs contributed approximately a total of 10 million dollars to federal election campaigns, whereas foreign agent expenditures added up to approximately 14 million dollars. Further, it may be noted that in contrast to foreign agents, domestic PACs are interested in a much broader range of economic policymaking than simply trade policy or other externally related matters. Thus, it becomes clear that in the trade policy arena, the extent of foreign agent activity was not of a lower order of magnitude than domestic lobbying. The influence on trade policy of this lobbying activity by domestic and foreign entities is what we study in the rest of this paper.

\section{Theory}

The theoretical framework we use closely parallels that of Grossman and Helpman (1994)-but with some important modifications to allow for the role of foreign lobbies. We provide here a brief description of the theoretical framework [referring the reader to the working-paper version of our paper, Gawande, Krishna, and Robbins (2004), for details]. Consider an open economy populated by individuals with identical preferences over consumption represented by the following utility function:

$$
U=c_{0}+\sum_{i} u_{i}\left(c_{i}\right)
$$

where $c_{0}$ denotes consumption of the numeraire good (good 0$)$, and $c_{i}$ denotes consumption of goods $i=1, \ldots, n$. Assume further that the subutilities $u_{i}$ are quadratic functions with parameters such that domestic demand for the nonnumeraire goods takes the linear form

$$
P_{i}=A-Q_{i}, \quad i=1, \ldots, n,
$$

where $Q_{i}$ denotes aggregate consumption of good $i$.

Good 0 is assumed to be produced from labor alone by Ricardian technology (with input-output coefficient equal to 1) and is assumed to be freely traded internationally in perfectly competitive markets. Goods $i=1, \ldots, n$ are assumed to be produced with constant-returns technologies using labor alone (or alternatively using fixed and specific capital, as in Grossman and Helpman, and technology that gives constant returns to labor), but are assumed to be sold in internationally segmented oligopolistically competitive markets with

\footnotetext{
${ }^{7}$ For a detailed discussion and accounting of the role of foreign agents in recent campaigns, see http://www.opensecrets.org.
} 
supply provided by fixed numbers of domestic and international firms (as in Brander \& Krugman, 1983), which produce at constant costs and compete in the domestic market in Cournot-Nash fashion.

As in Grossman and Helpman (1994), trade policy is determined by interactions between the government and organized lobbies-here representing (separately) domestic and foreign firms. Specifically, the government's objective function is assumed to be a weighted function of lobbying contributions and the three components of welfareconsumer surplus, producer surplus, and profits-in the following form:

$$
G=\sum_{i \in L^{h}} C_{i}^{h}+a\left(\sum_{i} n_{i}^{h} \pi_{i}^{h}+T R+C S\right)+b \sum_{i \in L^{\prime}} C_{i}^{\phi},
$$

where $L^{h}$ denotes the sectors with organized domestic lobbies, $C_{i}^{h}$ denotes lobbying contributions by the domestic lobby (if any) in $i, L^{f}$ denotes the set of organized foreign lobbies, $C_{f} f$ denotes foreign contributions, $T R$ denotes tariff revenues, $C S$ denotes consumer surplus, $\pi_{i}{ }^{h}$ denotes the profits earned by an individual domestic producer in sector $i, n_{i}^{h}$ denotes the number of domestic firms in sector $i, a$ is a constant reflecting the government's preference for welfare relative to domestic campaign contributions, and, finally, $b$ is a constant reflecting the government's preference for foreign contributions relative to domestic contributions.

The lobbies representing domestic and foreign firms in any sector would like trade policy to be set in a manner that suits them-for example, a domestic lobby in import-competing sector $i$ would typically want import barriers on imports of $i$ and import subsidies on imports of all other goods, whereas a foreign lobby in sector $i$ would want this government to subsidize the imports of $i$. Assuming efficient political interactions, we will have an outcome that maximizes the sum of surpluses that accrue to the interacting parties (the government and the lobbies, domestic and foreign). Letting $\alpha$ denote the fraction of the home population that is organized into any domestic lobby, we have that the trade policy vector chosen maximizes

$$
\begin{aligned}
& \sum_{i \in L^{h}} n_{i}^{h} \pi_{i}^{h}+\alpha(T R+C S)+a\left(\sum n_{i}^{h} \pi_{i}^{h}+T R+C S\right) \\
& \quad+b \sum_{i \in L^{f}} n_{i}^{f} \pi_{i}^{f},
\end{aligned}
$$

where $n_{i}^{f}$ denotes the number of foreign firms in sector $i$, and $\pi_{i}^{h}$ denotes profits earned by an individual foreign firm.

The first-order conditions to this maximization problem (along with a minor approximation) give us the following expression for equilibrium trade policy:

$$
\frac{\tau_{i}}{P_{i}}=\left(\frac{2 I_{i}^{h}}{a+\alpha}+\frac{2 a}{a+\alpha}\right)\left(\frac{X_{i}}{m_{i}}\right) \frac{1}{\left|\epsilon_{i}\right|}-\frac{2 b I_{i}^{f}}{a+\alpha}\left(\frac{X_{i}}{m_{i}}\right) \frac{1}{\left|\epsilon_{i}\right|},
$$

where $X_{i}$ denotes aggregate production of $i$ in the home economy, $m_{i}$ denotes imports, and $\epsilon_{i}$ is an imports elasticity measure-it measures the "observed" proportionate change in imports with changes in prices, that is, $\left(\frac{\partial m_{i}}{\partial P_{i}}\right) /\left(\frac{m_{i}}{P_{i}}\right)$, when the price changes are caused by changes in tariffs. Overall, the prediction of the model regarding the cross-sectional determinants of tariffs [as represented by equation (5) above] are quite intuitive. Sectors that are politically represented by organized domestic lobbies are, ceteris paribus, likely to receive more protection (that is, $I_{i}^{h}$ enters positively). Sectors in which there is foreign political presence are likely to receive less protection (that is,
$I_{i}^{f}$ enters negatively). Finally, sectors in which there is neither domestic political representation nor foreign political presence are predicted to receive positive protection (which should not be surprising, given the assumptions regarding the imperfectly competitive nature of the product market). ${ }^{8}$

\section{Econometric Specification, Data, and Estimation Methodology}

Equation (5) motivates our basic estimating equation. After the introduction of an (additive) error term $e_{i}$, it can be expressed as

$$
\begin{aligned}
\frac{t_{i}}{1+t_{i}}=\beta_{1} & {\left[\frac{X_{i}}{m_{i}} \cdot \frac{1}{\left|\epsilon_{i}\right|}\right]+\beta_{2}\left[I_{i}^{h} \cdot \frac{X_{i}}{m_{i}} \cdot \frac{1}{\left|\epsilon_{i}\right|}\right] } \\
& +\beta_{3}\left[I_{i}^{f} \cdot \frac{X_{i}}{m_{i}} \cdot \frac{1}{\left|\epsilon_{i}\right|}\right]+e_{i},
\end{aligned}
$$

where $t_{i}$ denotes the (effective) ad valorem import tax [that is, $\frac{\tau_{i}}{\left[P_{i}-\tau_{i}\right]}$ and where $\beta_{1}=\frac{2 a}{(a+\alpha)}, \beta_{2}=2 /(a+\alpha)$, and $\beta_{3}=\frac{-2 b}{(a+\alpha)}$. Clearly, $\beta_{1}$ and $\beta_{2}$ are predicted to be greater than zero and $\beta_{3}$ is less than 0 .

In the estimation of the equation (6) above we employ primarily data from the period 1978-1982. The study is conducted at the four-digit SIC level of disaggregation, and is focused on U.S. manufacturing industries. Issues pertaining to their measurement and those of the other variables are discussed at length below, and the appendix to Gawande, Krishna, and Robbins (2004) provides further details on their construction.

\section{A. Protection Measures}

The theory on which our model is founded simply dictates that the protection measure equals the proportional difference between domestic prices and world prices. In practice, however, choosing between alternative trade barrier measures in order to capture the extent of protection is a difficult (and familiar) problem. In a world in which tariffs are the only form of protection, the choice is obvious: the tariff rate itself is the precise measure of the gap between domestic and foreign prices. When nontariff barriers (NTBs) are in use instead, the situation is more difficult because we generally lack even moderately satisfactory measures of the tariff equivalents of those nontariff barriers. What many researchers have used instead is the coverage ratio, that is, the proportion of imports within any industry that is covered by NTBs, as the measure of protection by NTBs. When tariffs and NTBs are both known to be in use, it is hard to argue the merits of one protection measure over another. We are agnostic on this issue and simply report results using both tariff and NTB coverage ratios. ${ }^{9}$

${ }^{8}$ It is perhaps worth clarifying that the numbers of firms, $n_{i}^{f}$ and $n_{i}{ }^{h}$, and their individual outputs do not enter on the right-hand side of equation (5), because their effect is captured for most part by total imports and total domestic production as represented in equation (5) by $\mathrm{X} / \mathrm{m}$.

${ }^{9}$ The problems with using coverage ratios as a proxy for the extent of protection offered by NTBs are many and have been quite well discussed in the literature. Thus, for instance, the coverage ratio is an imprecise measure of nontariff protection for at least the reason that NTBs are heterogeneous in their intensity. That is, industries with a large fraction of products covered by very lenient NTBs would be measured with a high coverage ratio and deemed to be highly protected, whereas industries in which a smaller fraction of products are covered by highly restrictive barriers would be deemed to be less protected, and this may or may not reflect the aggregate extent of protection actually provided by the NTBs. 


\section{B. Foreign and Domestic Lobbying}

We compiled data on foreign political organizations using U.S. government reports on the administration of the FARA. As we have mentioned before, these are annual reports put together by the Attorney General's office for the U.S. Congress and contain detailed and extensive records of political spending patterns in the United States of foreign commercial entities from various countries (through so-called foreign agents based in the United States). All FARA entries were organized by industry, and the total spending by foreign commercial entities per unit value added of imports for each industry was obtained. Similarly, for domestic lobbies, data were organized by industry, and corporate lobby expenditures per unit value added were determined by industry [see the data appendix in Gawande, Krishna, and Robbins (2004) for details]. The compilation of this data and their organization are an innovation in the literature, and a distinctive contribution of this paper to it. The FARA data we organized and use primarily are from the years 1978-1982. In addition, to check robustness, we also use FARA data from the years 1972-1975. However, as we discuss later, the FARA reports are less detailed in this earlier time period, and so we are forced to organize and limit our estimation exercises with these data accordingly.

As in Goldberg and Maggi (1999), thresholds were used to determine whether the foreign-political-organization dummy variable was to be assigned a value of 1 . This is done with a view to allowing for a more continuous representation of the intensity of lobbying activity while remaining true to the theory, which explicitly requires a discrete zero-one variable to represent the existence of lobbies. We used several thresholds for the purpose of investigating the robustness of the results to a variety of definitions for $I^{*}$. The domestic political organization variable $I$ was also defined on the basis of thresholds. In the cases central to our discussion, the domestic political organization dummy was assigned a value of 1 if the mean of domestic PAC spending per thousand dollars of sectoral value added (in the period under study, 1978-1982) was in excess of 0.05 or 0.10 . Foreign political organization was assigned as follows. The percentile distribution of expenditures per unit value added was first determined. Four percentile thresholds, in increasing order of expenditures per unit value added, are presented in the table: the 0 th, the 25 th, the 50th, and the 75th percentiles. For any given threshold, say the 50th percentile, the sector was assigned an $I^{*}=1$ if that sector was in that percentile for all of the four years in the sample period $(1978,1979,1981$, and 1982). In sum, two thresholds ( 0.05 and 0.10 of PAC spending per thousand dollars of sectoral value added) were used to assign domestic political organization and four percentile thresholds were used to assign foreign political organization.

\section{Import Elasticities and Other Variables}

Import demand elasticities were taken from the well-known study by Sheills, Stern, and Deardorff (1986). These are estimated at the three-digit SIC level, and are replicated at our four-digit level here. ${ }^{10}$

We have nothing new to add to this issue here and, as we have just noted, simply proceed by using both tariff and NTB coverage ratios. We might note additionally that previous studies that have empirically examined the new generation of political economy models (such as Gawande and Bandhyopadhyay, 2000, and Goldberg and Maggi, 1999) have generally used only nontariff barriers to represent the level of trade protection. Our study is the first to use U.S. tariffs in this context.

10 The fact that most industry data (including those on political activity) are available at the four-digit level whereas data on elasticities are only available at the three-digit level poses a potential problem for us as to the
Further, because the import demand elasticities on the right-hand side of equation (6) are proxied by import demand elasticity estimates rather than actual measures, there is a potentially severe errors-invariables problem that must be dealt with, given the widely varying levels of precision associated with the estimates. We deal with this as in Gawande and Bandhyopadhyay (2000), where Fuller's (1986) method is used to mitigate the errors-in-variables problem inherent in the elasticity data. Finally, the inverse import penetration ratio, $X_{i} / m_{i}$, is taken directly from the annual survey of manufactures. ${ }^{.1}$

Estimation of equation (6) raises a number of issues. First, the right-hand-side variables-the import penetration ratio and the lobby dummies indicating whether or not a given sector is politically organized in the home country and abroad-are potentially endogenous. Moreover, what appears on the right-hand side is not simply a linear function of these endogenous variables, but is rather the sum of nonlinear products of these variables. In order to consistently estimate the structural coefficients of the system, we therefore use the twostage least squares estimator proposed by Kelejian (1971). The "exogenous" variables we use to form instruments are chosen on the basis of their correlation with the endogenous right-hand-side variables and their relative invariance, at least in the short run, to changes in trade policy. The capital-labor ratio $(K / L)_{i}$, the fraction of unskilled workers, the fraction of scientists, and the average output per firm, or average firm size (denoted here by Scale) are used to instrument for the import penetration ratio. As this literature has argued before, factorproportions models of international trade motivate the use of industry endowment ratios as an instrument for trade flows. On the other hand, the cross-sectional variation in Scale, that is, the average firm size, may be thought of as largely technologically determined (see, for instance, Brynjolfsson et al., 1994, and Kumar, Rajan, \& Zingales, 1999). It may be seen as a technological determinant of trade flows. Furthermore, the cross-sectional variation of both variables may be argued to be relatively invariant to trade policy changes in the short run. Seller concentration ratios are used to instrument for domestic political organization [as suggested by the well-known work of Olson (1965)], and the ratio of exports by foreigners to the United States to their worldwide exports in an industry (indicative of the relevance of the United States as an export market to these suppliers) is used additionally to instrument for foreign political organization. Given the nonlinearity of equation (6), reduced-form equations for the endogenous right-hand-side variables are estimated using as instruments the exogenous variables listed above, their quadratic terms, and their second-order cross-product terms in the first stage. ${ }^{12}$ Estimation in the second stage proceeds as usual.

level of disaggregation at which the analysis is to be conducted. Because much of the interest in the present exercise is in lobbying activity, and because econometric analyses conducted by us elsewhere (Gawande \& Bandhyopadhyay, 2000) suggest that elasticities bear relatively little of explanatory burden in this context, we choose to conduct the analysis at the four-digit level here.

11 Because the concordance from the system of trade data (the Tariff Schedule of the United States for these years, and the Harmonized Tariff Schedules in recent years) into the SIC system of industrial data is less than perfect, a few industries register zero imports. For these industries, the inverse import-penetration ratio is undefined, and they are dropped. In the end, our sample comprises 248 industries and accounts for over two-thirds of manufacturing value added.

${ }^{12}$ Kelejian (1971) shows that if the nonlinear expressions, for example, $x / m$. $I$, are regressed on linear, squared, and first-order cross products of the exogenous variables in the system, then the familiar two-stage least squares estimator may be used directly and has the desirable properties of consistency and asymptotic efficiency. 
TABLE 1-Descriptive Statistics

\begin{tabular}{lc}
\hline \multicolumn{1}{c}{ Variable } & $\begin{array}{c}\text { Sample Means } \\
\text { (Standard Deviations) }\end{array}$ \\
\hline Tariff $t$ & 0.065 \\
NTB coverage ratio & $(0.060)$ \\
& $(0.082)$ \\
$\frac{X}{m} \cdot \frac{1}{|\epsilon|}$ & $(0.137)$ \\
Import demand elasticity $\epsilon$ & 0.297 \\
Concentration ratio & $(1.641)$ \\
Scale & 1.49 \\
& $(1.100)$ \\
\% unionized & 0.4 \\
Wage & $(0.210)$ \\
K/L ratio & 0.1 \\
& $(0.010)$ \\
& 0.45 \\
& $(0.180)$ \\
\end{tabular}

The units of measurement and scaling are as follows. The output-to-imports ratio, $x / m$, is to be multiplied by 100; Scale is output per firm in billions of dollars; employment is in millions; Wage is average production wage in thousands of dollars per hour: $K / L$ is in units of ten thousand dollars per worker; the rest of the variables are in percentage terms or are unitless.

\section{Econometric Results}

Summary statistics for variables employed in our analysis are provided in table 1. The 1982 tariff data have a sample mean of $0.065 \%$. NTB coverage ratios have a mean value of 0.08 . Of primary interest are the absolute import demand elasticity $|\epsilon|$ which has a mean of 1.49 , and the inverse import penetration divided by the absolute import elasticity, or $(X / m) /|\epsilon|$, which has mean of 0.297 (when scaled by 100 , as we do throughout the analysis). As discussed earlier, we also estimate extended regressions in which the additional variables described in the table (concentration ratio, scale, percent unionized, wage, and $K / L$ ) are used.

Tables 2-5 present estimates of equation (6) obtained using a variety of measures to measure the level of protection and threshold levels to assign $I$ and $I^{*}$. In table 2, the protection measure is the tariff rate. A threshold of PAC spending per thousand dollars of sectoral value-added greater than 0.05 was used to assign the domestic political organization variable. As noted earlier, $I^{*}$ is assigned using four different quartile cutoffs (corresponding to the four columns of the table). Table 3 presents corresponding results with NTB coverage ratios used as the protection measure.

In tables 2 and 3 , the coefficients of central interest, $\beta_{2}$ and $\beta_{3}$, are statistically significant and have the signs predicted by the theory. $\beta_{2}$ is positive, implying that domestic political presence, holding all else constant, leads to higher trade barriers. $\beta_{3}$ is negative, implying that foreign political presence, holding all else constant, is correlated with lower tariffs. Notably, the magnitude of the foreign coefficient, $\beta_{3}$, tends to be higher when we consider higher percentile thresholds (with correspondingly smaller number of sectors with organized foreign representation). The closeness of the magnitudes of the coefficient estimates of $\beta_{2}$ and $\beta_{3}$ implies that in our theory the structural coefficient $b$, which measures the value of a foreign dollar in contributions relative to a domestic dollar, is approximately 1 . That is, the estimates suggest that the government places approximately equal weight on a dollar of domestic lobbying contribution and on a dollar of foreign lobbying contribution. This is an interesting and robust feature of our results. ${ }^{13}$

Tables 4 and 5 present results with thresholds for domestic PAC spending per thousand dollars of value added set at 0.10 instead. The results correspond closely to those presented in tables 2 and 3 . The coefficient $\beta_{2}$ is estimated significant and positive, and the coefficient $\beta_{3}$ is estimated significant and negative-just as the theory predicts. Here too, in almost all cases, the coefficient $\beta_{3}$ is estimated to be higher when higher percentile requirements are imposed on the foreign political organization variable.

Estimates of the coefficient $\beta_{1}$ are nearly always estimated to be insignificantly different from zero. It would appear from the definitions of $\beta_{1}$ and $\beta_{2}$ [given below equation (6)], that the structural parameter $a$ may be recovered as the ratio of $\beta_{1}$ to $\beta_{2}$, and this calculation would suggest that the value of $a$ is insignificantly different from 0 . That is, the estimates suggest that the government formulates trade policy almost entirely on the basis of political

${ }^{13}$ Formal statistical tests, not reported here, examining the equality of magnitudes of the coefficients $\beta_{2}$ and $\beta_{3}$ were conducted as well. In virtually all the parsimonious models using tariff and NTB data, this difference is found to not be statistically significant at the $10 \%$ level (the only exceptions being parsimonious models run with tariff data and using the 0 th percentile cutoff for $I^{*}$, in which case the difference is statistically significant at the $5 \%$ level). This is also true for all the extended models of tables 6 and 7, where domestic and foreign lobbying have equivalent effects on tariffs (in opposite directions).

Table 2.-Foreign Political Activity and Tariffs (1978-1982)

\begin{tabular}{|c|c|c|c|c|}
\hline \multirow[b]{2}{*}{ Parameter } & \multicolumn{4}{|c|}{$I^{*}$ Expenditures } \\
\hline & 0th Percentile & 25th Percentile & 50th Percentile & 75th Percentile \\
\hline$\beta_{1}$ & $\begin{array}{c}-0.007 \\
(0.606)\end{array}$ & $\begin{array}{c}-0.011 \\
(0.940)\end{array}$ & $\begin{array}{c}-0.015 \\
(1.265)\end{array}$ & $\begin{array}{c}-0.015 \\
(1.315)\end{array}$ \\
\hline$\beta_{2}$ & $\begin{array}{c}0.259 \\
(4.203)\end{array}$ & $\begin{array}{c}0.334 \\
(5.373)\end{array}$ & $\begin{array}{c}0.359 \\
(5.588)\end{array}$ & $\begin{array}{c}0.347 \\
(5.726)\end{array}$ \\
\hline$\beta_{3}$ & $\begin{array}{c}-0.766 \\
(1.305)\end{array}$ & $\begin{array}{c}-0.241 \\
(2.860)\end{array}$ & $\begin{array}{c}-0.29 \\
(3.282)\end{array}$ & $\begin{array}{c}-0.286 \\
(3.329)\end{array}$ \\
\hline$L$ & 161.86 & 180.237 & 174.827 & 180.016 \\
\hline$\%$ Obs with $I^{*}=1$ & 0.52 & 0.22 & 0.08 & 0.04 \\
\hline$\%$ Obs with $I=1$ & 0.65 & 0.65 & 0.65 & 0.65 \\
\hline AIC & -1.28 & -1.43 & -1.39 & -1.43 \\
\hline SIC & 0.62 & 0.69 & 0.67 & 0.69 \\
\hline
\end{tabular}

In each of the regressions, the domestic lobbies are taken to be organized if PAC expenditure for every thousand dollars of sectoral value added is greater than 0.05. AIC and SIC denote the Akaike Informatio Criterion and the Schwarz Information Criterion, respectively. The figures in parentheses are $t$-statistics (absolute values). $L$ denotes the log likelihood ratio. \% Obs with $l^{*}=1$ and $\%$ Obs with $I=1$ denote the percentage of sectors for which the dummy variables $I^{*}$ and $l$ were assigned a value of 1 
TABle 3.-Foreign Political Activity AND NTBs (1978-1982)

\begin{tabular}{|c|c|c|c|c|}
\hline \multirow[b]{2}{*}{ Parameter } & \multicolumn{4}{|c|}{$I^{*}$ Expenditures } \\
\hline & 0th Percentile & 25th Percentile & 50th Percentile & 75th Percentile \\
\hline $\boldsymbol{\beta}_{1}$ & $\begin{array}{c}-0.012 \\
(0.578)\end{array}$ & $\begin{array}{c}-0.015 \\
(0.748)\end{array}$ & $\begin{array}{c}-0.019 \\
(0.950)\end{array}$ & $\begin{array}{c}-0.019 \\
(0.962)\end{array}$ \\
\hline $\boldsymbol{\beta}_{2}$ & $\begin{array}{c}0.308 \\
(2.955)\end{array}$ & $\begin{array}{c}0.442 \\
(4.151)\end{array}$ & $\begin{array}{c}0.461 \\
(4.267)\end{array}$ & $\begin{array}{c}0.443 \\
(4.311)\end{array}$ \\
\hline$\beta_{3}$ & $\begin{array}{r}-0.006 \\
(0.061)\end{array}$ & $\begin{array}{c}-0.263 \\
(1.824)\end{array}$ & $\begin{array}{c}-0.301 \\
(2.022)\end{array}$ & $\begin{array}{c}-0.283 \\
(1.945)\end{array}$ \\
\hline$L$ & 31.68 & 46.215 & 45.451 & 49.378 \\
\hline$\%$ Obs with $I^{*}=1$ & 0.52 & 0.22 & 0.08 & 0.04 \\
\hline$\%$ Obs with $I=1$ & 0.43 & 0.43 & 0.43 & 0.43 \\
\hline AIC & -0.23 & -0.35 & -0.34 & -0.37 \\
\hline SIC & 0.09 & 0.15 & 0.15 & 0.17 \\
\hline
\end{tabular}

contributions, with little regard for welfare. That conclusion, however, is not necessarily warranted here: Using the coefficient $\beta_{2}$ to infer the value of $a$, after using the fact that the fraction of the population that is organized has to be necessarily less than 1 (that is, $\alpha<1$ ), implies an implausibly high value of $a$ instead. ${ }^{14}$ This should perhaps not be surprising: that plausible estimates of the parameter $a$ have proven difficult to obtain is a well-known point in the literature by now (see Goldberg \& Maggi, 1999, and Gawande \& Bandhyopadhyay, 2000). ${ }^{15}$

The results based on the 1978-1982 FARA data may then be summarized as follows: ceteris paribus, tariffs and NTB coverage ratios are strongly positively correlated with the presence of organized import-competing lobbies and negatively related to organized foreign lobbies. This is in accord with the theory. The quantitative implications of the results are as follows. Consider the 50th-percentile cutoff

\footnotetext{
${ }^{14}$ Note that given our scaling by 100 of $(X / m) /|\epsilon|$, we have $2 /(a+\alpha)=$ $\beta_{2} / 100$. Given the estimated values of $\beta_{2}$ (around $0.2-0.5$ ), this implies a very high value for $a$ when $\alpha<1$.

${ }^{15}$ We should note, however, that problematic estimates of $a$ need not lead the reader to be skeptical as to whether the estimates of $\beta_{2}$ and $\beta_{3}$ are informative about the relative impact of other determinants of trade policy (such as domestic political organization relative to foreign political organization). As modeled, the "variable" $a$ is constant across industries, whereas the other variables vary in the cross section. That is to say, the former relates to the level of protection, whereas the latter also related to the cross-sectional variation in protection.
}

definition for $I^{*}$ in table 2 . The estimated value 0.359 of $\beta_{2}$ implies that if an industry is domestically organized, then an increase of 0.1 in the scaled value of the inverse ratio of import penetration to import elasticity (where the scaling is 100 ) will raise the ad valorem tariff by 0.036 . The estimated value -0.29 of $\beta_{3}$ implies that if an industry has foreign political organization, then the same increase in the inverse ratio of import penetration to import elasticity will lower the ad valorem tariff by 0.017 . Hence, we see a countervailing influence on the U.S. tariff of a similar magnitude exerted by foreign lobbying. A more unconditional inference about lobbying organization and its impact on tariffs may also be made: Consider a representative estimate of $\beta_{2}$ and $\beta_{3}$ of, say, 0.2 . Given the mean value of $\frac{x}{m|\epsilon|}$ of about 0.3 (see table 1 for descriptive statistics), this implies that on average, holding all else constant, the presence of an organized foreign lobby lowers tariffs in that industry by approximately 6 percentage points (lowers the tariff rate from, say, $12 \%$ to $6 \%$ ). Conversely, the presence of an organized domestic lobby raises the tariff rate in that industry by 7.5 percentage points. These estimates suggest economically significant effects of domestic and foreign lobbying.

Finally, we observe the intuitively appealing result that these effects are larger when $I$ and $I^{*}$ are measured at higher percentile or spending requirements. Although the theory does not explicitly recognize any fixed costs of lobby formation and organization, in practice

TABle 4.-Foreign Political Activity and TARIFFs (1978-1982)

\begin{tabular}{|c|c|c|c|c|}
\hline \multirow[b]{2}{*}{ Parameter } & \multicolumn{4}{|c|}{$I^{*}$ Expenditures } \\
\hline & Oth Percentile & 25th Percentile & 50th Percentile & 75th Percentile \\
\hline$\beta_{1}$ & $\begin{array}{c}0.007 \\
(0.576)\end{array}$ & $\begin{array}{c}0.003 \\
(0.197)\end{array}$ & $\begin{array}{r}-0.004 \\
(0.303)\end{array}$ & $\begin{array}{c}-0.004 \\
(0.341)\end{array}$ \\
\hline$\beta_{2}$ & $\begin{array}{c}0.26 \\
(2.689)\end{array}$ & $\begin{array}{c}0.631 \\
(4.031)\end{array}$ & $\begin{array}{c}0.665 \\
(4.258)\end{array}$ & $\begin{array}{c}0.596 \\
(4.532)\end{array}$ \\
\hline$\beta_{3}$ & $\begin{array}{r}-0.062 \\
(0.870)\end{array}$ & $\begin{array}{c}-0.511 \\
(3.108)\end{array}$ & $\begin{array}{r}-0.564 \\
(3.383)\end{array}$ & $\begin{array}{r}-0.509 \\
(3.523)\end{array}$ \\
\hline$L$ & 151.61 & 124.506 & 118.192 & 138.408 \\
\hline$\%$ Obs with $I^{*}=1$ & 0.52 & 0.22 & 0.08 & 0.04 \\
\hline$\%$ Obs with $I=1$ & 0.65 & 0.65 & 0.65 & 0.65 \\
\hline AIC & -1.20 & -0.98 & -0.93 & -1.09 \\
\hline SIC & 0.58 & 0.47 & 0.44 & 0.52 \\
\hline
\end{tabular}

In each of the regressions, the domestic lobbies are taken to be organized if PAC expenditure for every thousand dollars of sectoral value added is greater than 0.10. AIC and SIC denote the Akaike Information Criterion and the Schwarz Information Criterion, respectively. The figures in parentheses are $t$-statistics (absolute values). $L$ denotes the log likelihood ratio. \% Obs with $I^{*}=1$ and $\%$ Obs with $I=1$ denote the fractions of the total sample for which the dummy variables $I^{*}$ and $I$ were assigned a value of 1 . 
TABle 5.-Foreign Political Activity and NTBs (1978-1982)

\begin{tabular}{|c|c|c|c|c|}
\hline \multirow[b]{2}{*}{ Parameter } & \multicolumn{4}{|c|}{$I^{*}$ Expenditures } \\
\hline & $\begin{array}{c}\text { 0th } \\
\text { Percentile }\end{array}$ & 25th Percentile & 50th Percentile & 75th Percentile \\
\hline$\beta_{1}$ & $\begin{array}{c}0.008 \\
(0.429)\end{array}$ & $\begin{array}{c}0.007 \\
(0.379)\end{array}$ & $\begin{array}{c}0.002 \\
(0.105)\end{array}$ & $\begin{array}{c}0.002 \\
(0.119)\end{array}$ \\
\hline$\beta_{2}$ & $\begin{array}{c}0.186 \\
(1.243)\end{array}$ & $\begin{array}{c}0.639 \\
(2.736)\end{array}$ & $\begin{array}{c}0.648 \\
(2.861)\end{array}$ & $\begin{array}{c}0.579 \\
(2.921)\end{array}$ \\
\hline$\beta_{3}$ & $\begin{array}{c}0.08 \\
(0.730)\end{array}$ & $\begin{array}{c}-0.436 \\
(1.778)\end{array}$ & $\begin{array}{c}-0.458 \\
(1.891)\end{array}$ & $\begin{array}{c}-0.396 \\
(1.818)\end{array}$ \\
\hline$L$ & 44.016 & 25.111 & 25.937 & 36.782 \\
\hline$\%$ Obs with $I^{*}=1$ & 0.52 & 0.22 & 0.08 & 0.04 \\
\hline$\%$ Obs with $I=1$ & 0.65 & 0.65 & 0.65 & 0.65 \\
\hline AIC & -0.33 & -0.18 & -0.19 & -0.27 \\
\hline SIC & 0.14 & 0.07 & 0.07 & 0.11 \\
\hline
\end{tabular}

In each of the regressions, the domestic lobbies are taken to be organized if PAC expenditure for every thousand dollars of sectoral value added is greater than 0.10. AIC and SIC denote the Akaike Information Criterion and the Schwarz Information Criterion, respectively. See main text for details. The figures in parentheses are $t$-statistics (absolute values). $L$ denotes the log likelihood ratio. \% Obs with $I^{*}=1$ and \% Obs with $I=1$ denote the fractions of the total sample for which the dummy variables $I^{*}$ and $l$ were assigned a value of 1 .

it is only after spending exceeds certain amounts that we would expect the industry to be politically organized for lobbying. The results suggest the presence of such fixed costs. ${ }^{16}$

As the results reported in tables 2 through 5 indicate, our results are robust to changes in the ways in which the data are handled (by varying thresholds levels for the assignment of $I$ and $I^{*}$ or the measures of protection itself). We have also conducted a number of additional robustness checks. We discuss these here briefly. ${ }^{17}$ The first set of robustness checks involved varying the time period of our sample. The fact that our sample follows a major multilateral international trade negotiation round (the Tokyo round of the GATT) may raise doubts as to whether other factors such as international bargaining influenced our estimates. ${ }^{18}$ We should note first that proportionality associated with the tariff reduction schemes implemented after the Tokyo round mitigates this concern somewhat. Nevertheless, we repeated our exercises using trade protection and FARA data from the period 1972-1975 (which preceded the Tokyo round, which only started in 1976). ${ }^{19}$ The limitation on the FARA data from this time period is that we do not have detailed data in the FARA reports on foreign agent activities. Specifically, there are no data for this time period on the actual expenditures by foreign lobbyists, and there are no data indicating specifically whether or not the foreign lobbyists made any effort to contact the U.S. government. Lacking any data on actual expenditures, we proceeded first by using simply the 0th percentile criterion (that is, a sector is assigned $I^{*}=1$ if it simply appears in the FARA database in each of the years under consideration). In these runs, the theory still finds a confirmation in the data:

\footnotetext{
${ }^{16}$ Of course, other explanations are possible, and our analysis does no confirm this as the only explanation for the observed pattern of coefficient estimates. The fixed-costs explanation, however, seems to be a compelling one. For a recent analytical investigation of the issue of endogenous determination of lobbies (in a Grossman-Helpman context) in the presence of fixed costs of lobby formation, see Mitra (1999).

${ }_{17}$ We do not present the results of these tests in detail here, in the interest of brevity. They are reported instead in the working paper version of this paper, Gawande, Krishna, and Robbins (2004).

${ }^{18}$ Thus it is perhaps worth pointing out that this is a standing problem that has not adequately been dealt with in the literature-the majority of studies on endogenous protection have simply ignored it.

${ }^{19}$ Of course, this too was preceded by other GATT negotiation rounds. Nevertheless, estimates obtained using data before the Tokyo round are roughly similar in magnitude to those obtained using data after the Tokyo round-suggesting that equilibrium outcomes in trade negotiations too reflect the same cross-sectional pressures.
}

the coefficient $\beta_{2}$ is estimated significant and positive, and the coefficient $\beta_{3}$ is estimated significant and negative. Keeping in mind the extent of persistence of lobbying activity observed in data on both domestic and foreign lobbying, and in order to exploit the more detailed information that we have in our FARA data from in the later period, we estimated equation (6) differently using data on tariffs and import penetration from the earlier period (1972-1975) and political organization from the later period (1978-1982). This amounts to assuming that the distribution of lobbying expenditures across industries in the period 1972-1975 was identical to the distribution in the period 1978-1982. The results showed a remarkable degree of similarity with the results reported in tables $2-5$. Foreign organization was nearly always negatively correlated with trade barriers, and domestic lobbying nearly always positively so. The consistency of results using tariff rates from the period prior to the Tokyo round with those after the Tokyo round should perhaps not be greatly surprising. It is only indicative of the fact that even when trade barriers are negotiated internationally, equilibrium outcomes are subject to the very same (or similar) domestic lobbying pressures that would operate if international negotiations were absent. The fact that lobbying data from a later period are used in a regression with trade policy from a prior period makes these results less reliable, but it is heartening to see that our earlier results are not contradicted by this run.

A second set of robustness checks involved varying the protection measure. In addition to the overall NTB coverage ratio, we also separated NTBs into simply quantitative NTBs and price NTBs and found the results to be largely invariant to this finer categorization. Foreign lobbying appears to reduce protection, and domestic lobbying appears to raise it.

A separate analysis was also conducted in which an additional criterion was used to assign the foreign political organization variable-the FARA report had to have indicated specifically that the foreign agent had made efforts to contact officials from the U.S. government. The results remain qualitatively the same and show only minor quantitative change.

Finally, because the left-hand-side variable in equation (6) is censored below 0 for some industries (for example, import subsidies, which are akin to negative tariffs, are not measured in the tariff data), we combined the method of Smith and Blundell (1986) with that of Kelejian (1971) to obtain estimates of the tobit model (6). The results seem invariant to this change (qualitatively speaking). Perhaps this should not be so surprising: the extent of censoring in the tariff data 
Table 6.-Foreign Political Activity and Tariffs-Extended Specification (1978-1982)

\begin{tabular}{|c|c|c|c|c|}
\hline \multirow[b]{2}{*}{ Parameter } & \multicolumn{4}{|c|}{$I^{*}$ Expenditures } \\
\hline & 0th Percentile & 25th Percentile & 50th Percentile & 75th Percentile \\
\hline$\beta_{1}$ & $\begin{array}{c}0.001 \\
(0.143)\end{array}$ & $\begin{array}{c}-0.002 \\
(0.273)\end{array}$ & $\begin{array}{c}-0.004 \\
(0.531)\end{array}$ & $\begin{array}{c}-0.004 \\
(0.587)\end{array}$ \\
\hline$\beta_{2}$ & $\begin{array}{c}0.154 \\
(3.271)\end{array}$ & $\begin{array}{c}0.157 \\
(3.297)\end{array}$ & $\begin{array}{c}0.151 \\
(3.053)\end{array}$ & $\begin{array}{c}0.152 \\
(3.057)\end{array}$ \\
\hline$\beta_{3}$ & $\begin{array}{c}-0.12 \\
(3.235)\end{array}$ & $\begin{array}{c}-0.175 \\
(3.123)\end{array}$ & $\begin{array}{c}-0.165 \\
(2.717)\end{array}$ & $\begin{array}{c}-0.159 \\
(2.729)\end{array}$ \\
\hline Concentration ratio & $\begin{array}{c}0.083 \\
(2.883)\end{array}$ & $\begin{array}{c}0.069 \\
(2.493)\end{array}$ & $\begin{array}{c}0.072 \\
(2.631)\end{array}$ & $\begin{array}{c}0.073 \\
(2.654)\end{array}$ \\
\hline Scale & $\begin{array}{c}-0.209 \\
(0.661)\end{array}$ & $\begin{array}{c}-0.463 \\
(1.593)\end{array}$ & $\begin{array}{r}-0.482 \\
(1.670)\end{array}$ & $\begin{array}{c}-0.458 \\
(1.578)\end{array}$ \\
\hline$\%$ unionized & $\begin{array}{c}0.068 \\
(2.635)\end{array}$ & $\begin{array}{c}0.082 \\
(3.213)\end{array}$ & $\begin{array}{c}0.082 \\
(3.200)\end{array}$ & $\begin{array}{c}0.075 \\
(2.978)\end{array}$ \\
\hline Wage & $\begin{array}{r}-0.342 \\
(0.169)\end{array}$ & $\begin{array}{r}-0.612 \\
(0.309)\end{array}$ & $\begin{array}{c}-0.886 \\
(0.441)\end{array}$ & $\begin{array}{c}-0.695 \\
(0.348)\end{array}$ \\
\hline$K / L$ & $\begin{array}{c}-0.003 \\
(2.616)\end{array}$ & $\begin{array}{c}-0.002 \\
(2.347)\end{array}$ & $\begin{array}{c}-0.003 \\
(2.159)\end{array}$ & $\begin{array}{c}-0.002 \\
(2.214)\end{array}$ \\
\hline$L$ & 295.82 & 304.2 & 305.9 & 304.8 \\
\hline$\%$ Obs with $I^{*}=1$ & 0.52 & 0.22 & 0.08 & 0.04 \\
\hline$\%$ Obs with $I=1$ & 0.65 & 0.65 & 0.65 & 0.65 \\
\hline AIC & -2.32 & -2.39 & -2.40 & -2.39 \\
\hline SIC & 1.10 & 1.14 & 1.14 & 1.14 \\
\hline
\end{tabular}

In each of the regressions, the domestic lobbies are taken to be organized if PAC expenditure for every thousand dollars of sectoral value added is greater than 0.05 . See main text for details. The figures in parentheses are $t$-statistics (absolute values). $L$ denotes the log-likelihood ratio. \% Obs with $I^{*}=1$ and $\%$ Obs with $I=1$ denote the fraction of the total sample for which the dummy variables $I^{*}$ and $I$ were assigned a value of 1 .

is small, and the tobit results should therefore have been close to the linear instrumental variables (IV) estimates.

\section{A. Extended Regressions}

The preceding regressions have all tested the implications of the theory in strict form-restricting the number of variables on the right-hand side to those predicted narrowly by the theory. However, the earlier literature on endogenous trade policy has suggested several other variables that may be relevant in explaining protection [see, for example, Baldwin (1985), Trefler (1993), and Gawande (1998) for a detailed discussion]. Thus, for instance, one may expect industries that have higher seller concentration (and thus presumably are more easily organized) or higher degrees of unionized workers to be better able to secure protection. Industries with greater numbers of low-skilled and low-wage workers, or simply labor-intensive industries, may be more likely to get protection from governments which have social-justice motivations or are subject to democratic pressures. Tables 6 and 7 present our final set of IV results for tariffs and NTBs, respectively, in which the specification includes a number of these additional variables on the right-hand side. ${ }^{20}$ We note first that the coefficients on many of the variables have the signs suggested and confirmed in the earlier literature. ${ }^{21}$ Thus, unionization rates show up as positively affecting the protection rates, as do concentration ratios. Laborintensive sectors (which are more likely importable sectors) receive higher protection (as indicated by the negative coefficient on $K / L$ ), as do industries with lower wages (and presumably greater numbers of low-skilled workers). Importantly, both our coefficients of central

\footnotetext{
${ }^{20}$ For brevity, we have only presented results where the threshold for $I$ is set at 0.05 as in tables 2 and 3 . Using the higher threshold of 0.10 or 0.25 did not make any qualitative difference to our results.

${ }^{21}$ A detailed discussion of the determinants of trade policy discussed in the earlier empirical literature and the contrast in methodology with recent structural attempts is provided in the recent survey by Gawande and Krishna (2003).
}

concern, $\beta_{2}$ and $\beta_{3}$, retain their signs and statistical significance, although they both see a drop in magnitudes.

\section{B. Model Comparisons}

Our final set of results concerns the comparison of the extended models presented in tables 6 and 7 with the parsimonious specification (5) implied by the theory. We perform these comparisons of these nested models using the Akaike information criteria (AIC) and the Schwarz information criteria (SIC). ${ }^{22}$ The augmented model with nine explanatory variables outperforms the corresponding parsimonious model on both criteria. For example, the AIC value -2.32 in the second column of table 6 is lower than the AIC value -1.28 in the second column of table 2 . Hence, the extended model (at the 0th percentile $I^{*}$ cutoff) is preferred over its smaller counterpart by the Akaike criterion. The SIC value 1.10 in the second column of table 6 is higher than the SIC value 0.62 in the second column of table 2 . The extended model is thus preferred over its smaller counterpart even by the Schwarz criterion. The preference for the extended model is unanimous across all models estimated, as well as across both measures of protection-tariffs and NTBs. An implication of this finding is that the parsimonious model does omit possibly important influences. In particular, the results from the extended model suggest that the lobbying and electoral influence of unions and the determination of lobbying organization itself are among the important issues that deserve formal treatment.

22 These are preferred over other criteria such as adjusted $R^{2}$ because they penalize excessive parameterization and reward parsimony. Given their formulation, lower AIC values are preferred and higher SIC values are preferred. Although both criteria penalize the use of additional regressors more strictly than does the adjusted $R^{2}$, the SIC imposes this penalty more severely than does the AIC. 
TABLE 7.-Foreign Political Activity AND NTBs (1978-1982)

\begin{tabular}{|c|c|c|c|c|}
\hline \multirow[b]{2}{*}{ Parameter } & \multicolumn{4}{|c|}{$I^{*}$ Expenditures } \\
\hline & 0th Percentile & 25th Percentile & 50th Percentile & 75th Percentile \\
\hline$\beta_{1}$ & 0.0001 & $\begin{array}{c}-0.003 \\
(0.188)\end{array}$ & $\begin{array}{l}-0.005 \\
-0.322\end{array}$ & -0.006 \\
\hline$\beta_{2}$ & 0.285 & $\begin{array}{c}0.323 \\
(2875)\end{array}$ & 0.311 & 0.325 \\
\hline \multirow[t]{2}{*}{$\beta_{3}$} & -0.115 & $\begin{array}{l}(2.8 / 5) \\
-0.224\end{array}$ & $\begin{array}{r}2.062 \\
-0.206\end{array}$ & $\begin{array}{l}(2.158) \\
-0.22\end{array}$ \\
\hline & $(1.330)$ & $(1.706)$ & -1.441 & (1.593) \\
\hline \multirow[t]{2}{*}{ Concentration ratio } & 0.076 & 0.062 & 0.066 & 0.067 \\
\hline & $(1.135)$ & $(0.950)$ & 1.017 & $(1.025)$ \\
\hline \multirow[t]{2}{*}{ Scale } & 1.412 & 1.187 & 1.162 & 1.201 \\
\hline & $(1.906)$ & $(1.741)$ & 1.709 & $(1.745)$ \\
\hline \multirow[t]{2}{*}{$\%$ unionized } & 0.058 & 0.076 & 0.075 & 0.068 \\
\hline & $(0.943)$ & $(1.262)$ & 1.239 & (1.129) \\
\hline \multirow[t]{2}{*}{ Wage } & -3.053 & -3.737 & -4.039 & -3.989 \\
\hline & $(0.642)$ & $(0.804)$ & -0.852 & $(0.842)$ \\
\hline \multirow[t]{2}{*}{$K / L$} & -0.0001 & 0.003 & 0.001 & 0.0005 \\
\hline & $(0.047)$ & $(0.118)$ & 0.217 & $(0.199)$ \\
\hline$L$ & 84.37 & 92.87 & 93.3 & 90.9 \\
\hline$\%$ Obs with $I^{*}=1$ & 0.52 & 0.22 & 0.08 & 0.04 \\
\hline$\%$ Obs with $I=1$ & 0.65 & 0.65 & 0.65 & 0.65 \\
\hline AIC & -0.62 & -0.68 & -0.688 & -0.67 \\
\hline SIC & 0.25 & 0.29 & 0.287 & 0.28 \\
\hline
\end{tabular}

In each of the regressions, the domestic lobbies are taken to be organized if PAC expenditure for every thousand dollars of sectoral value added is greater than 0.05 . See main text for details. The figures in parentheses are $t$-statistics (absolute values). $L$ denotes the $\log$ likelihood ratio. \% Obs with $I^{*}=1$ and $\%$ Obs with $I=1$ denote the fraction of the total sample for which the dummy variables $I^{*}$ and $I$ were assigned a value of 1 .

\section{Conclusions}

We closeby discussing some limitations of the analysis undertaken in this paper (which, it might be noted, it shares with much of the literature on the topic). Perhaps most important is the measurement of domestic and foreign lobbying activity. Domestic lobbies in this analysis are identified by the extent of their political contributions. However, the extent to which this spending is aimed at influencing trade policy (as opposed to other domestic policies) is not identified. The efforts of foreign lobbies are certainly more likely directed to international policy, but whether this is trade policy or policy with respect to, say, foreign direct investment is not identified. Finally, with respect to both domestic and foreign lobbies, a significant difficulty here is the fact that neither the theoretical model nor the empirical analysis takes into account the existence of multilateral policy settings such as the WTO where governments negotiate over trade policy (and where their negotiating positions are themselves influenced directlyby domestic and foreign lobbies). Though this criticism loses its force if it is the very same domestic and foreign industries as are active in the domestic market that are politically active in the different political arenas, this may not always be the case. Thus, although the incorporation of foreign lobbies, as in this work, provides a richer characterization of the policymaking process than was previously available, much further research remains necessary.

\section{REFERENCES}

Baldwin, Robert, The Political Economy of US Import Policy (Cambridge, MA: MIT Press, 1985).

Brander, James, and Paul Krugman, "A Reciprocal Dumping Model of International Trade," Journal of International Economics 15 (1983), 313-321.

Brynjolfsson, Erik, Thomas Malone, Vijay Gurbaxani, and Anil Kambil, "An Empirical Analysis of the Relationship between Information Technology and Firm Size," Management Science 40:12 (1994), 1628-1644.

Corrado, Anthony, Thomas Mann, Daniel Ortiz, Trevor Potter, and Franl Sorauf, Campaign Finance Reform: A Sourcebook (Washington: Brookings Institution Press, 1997).
Fuller, William, Measurement Error Models (New York: Wiley, 1986).

Gawande, Kishore, "Comparing Theories of Endogenous Protection: Bayesian Comparison of Tobit Models Using Gibbs Sampling Output," this REVIEW, 80:1 (1998), 128-140.

Gawande, Kishore, and Usree Bandhyopadhyay, "Is Protection for Sale? A Test of the Grossman-Helpman Theory of Endogenous Protection," this REVIEW, 82 (2000), 139-152.

Gawande, Kishore, and Pravin Krishna, "The Political Economy of Trade Policy: Empirical Approaches," in Eun Kwan Choi and James Harrigan (Eds.), Handbook of International Trade (New York: Basil Blackwell, 2003).

Gawande, Kishore, Pravin Krishna, and Michael J. Robbins, "Foreign Lobbies and US Trade Policy," NBER working paper no. 10205 (2004).

Goldberg, Pinelopi, and Giovanni Maggi, "Protection for Sale: An Empirical Investigation," American Economic Review 89 (1999), $1135-1155$.

Gene, Grossman, and Elhanan Helpman, "Protection for Sale," American Economic Review 84 (1994), 833-850.

Hillman, Arye, and Heinrich Ursprung, "Domestic Politics, Foreign Interests, and International Trade Policy," American Economic Review 78 (1988), 729-745.

Kelejian, Harry, "Two Stage Least Squares and Econometric Systems Linear in Parameters but Non-linear in the Endogenous Variables," Journal of the American Statistical Association 66 (1971), 373-374.

Kumar, Krishna, Raghuram Rajan, and Luigi Zingales, "What Determines Firm Size?" NBER working paper no. 7208 (1999).

Mitra, Devashish, "Endogenous Lobby Formation and Endogenous Protection: A Long-Run Model of Trade Policy Determination," American Economic Review 89 (1999), 1116-1134.

Olson, Mancur, The Logic of Collective Action (Cambridge, MA: Harvard University Press, 1965).

Rodrik, Dani, "Political Economy of Trade Policy," in Gene Grossman and Kenneth Rogoff (Eds.), Handbook of International Economics, volume III (North Holland, 1995).

Shiells, Clinton, Robert Stern, and Alan Deardorff, "Estimates of the Elasticities of Substitution between Imports and Home Goods for the United States," Weltwirtschaftliches-Archiv 122 (1986), 497-519.

Smith, Richard, and Richard Blundell, "An Exogeneity Test for a Simultaneous Equation Tobit Model with an Application to Labor Supply," Econometrica 54 (1986), 679-686.

Trefler, Daniel, "Trade Liberalization and the Theory of Endogenous Protection: An Econometric Study of U.S. Import Policy," Journal of Political Economy 101 (1993), 138-160. 